\title{
Evaluation of the Influence of Shale on the Petrophysical Properties of Hydrocarbon-Bearing Reservoir Sand in "CAC" Field in the Niger Delta, Nigeria
}

\author{
Charles C. Ugbor ${ }^{1}$, Chinwe Adaobi Obumselu ${ }^{*}$, Jethro 0. Ogboke ${ }^{2}$ \\ ${ }^{1}$ Department of Geology, University of Nigeria, Nsukka, Enugu State, Nigeria \\ ${ }^{2}$ NNPC. Lagos, Nigeria \\ Email: *chinweobumselu@gmail.com
}

How to cite this paper: Ugbor, C.C., Obumselu, C.A. and Ogboke, J.O. (2022) Evaluation of the Influence of Shale on the Petrophysical Properties of Hydrocarbon-Bearing Reservoir Sand in "CAC" Field in the Niger Delta, Nigeria. International Journal of Geosciences, 13, 71-92.

https://doi.org/10.4236/ijg.2022.131005

Received: September 22, 2021

Accepted: January 27, 2022

Published: January 30, 2022

Copyright $\odot 2022$ by author(s) and Scientific Research Publishing Inc. This work is licensed under the Creative Commons Attribution International License (CC BY 4.0).

http://creativecommons.org/licenses/by/4.0/

\begin{abstract}
This study aims at evaluating the influence of the presence of shale on the quality of reservoir sand in "CAC-Field", Coastal swamp Niger Delta by integrating suites of well logs and 3D pre-stack seismic data. Shales in the reservoir pose interpretation challenges as they form baffles to fluid flow and reduce effective porosity. The data used included well logs (density, gamma ray, neutron, resistivity) and 3D seismic data. Petrel and Interactive Petrophysics software were adopted for the analyses. The Vclay/effective porosity cross-plots were used to determine the clay distribution patterns hence the influence of shale on the petrophysical properties of the hydrocarbon reservoir. Result of the well correlation yielded 12 reservoirs with 4 (RES 4 - RES 7) being hydrocarbon bearing and laterally continuous across the 4 wells, (CAC-1 - CAC-4) forming the focus of the study. Evidence of an NW-SE trending delta progradation in the CAC field is represented by the increasing sandiness downdip, at both intermediate and the shallow horizons. Thickening of the reservoir in some instances may be structurally controlled due to faulting. The results from the petrophysical evaluation show Vclay ranges of $13 \%-21 \%$ and good to very good porosity values that vary from $15 \%-25 \%$. The permeability range from $240.49-2406.49 \mathrm{mD}$ except for the sands in RES 7, CAC-3 well where the permeability was low $(91 \mathrm{mD})$. Additionally, the Vclay/Effective Porosity cross-plots indicate essentially laminated and structural clay types with few dispersed clay in RES 7, CAC-3 well. The existence of these 3 clay types did not significantly influence the quality of the sands containing the hydrocarbon in the area, except in RES 7, CAC-3. The compartmentalizing effect of the laminated clay/shale could only possibly affect
\end{abstract}


the vertical flow due to possible baffles to the vertical flow, but the horizontal flow may not have been impeded significantly. The study of the type and pattern of clay has helped to better evaluate the quality and mobility trend of the hydrocarbon in the CAC field.

\section{Keywords}

Petrophysical Properties, Reservoir Quality, Shaliness, Permeability, Cross-Plot, Hydrocarbon

\section{Introduction}

Petrophysical study deals with the physical and chemical properties of rock and their interaction with fluids [1]. Some of these properties include lithology, porosity, net-to-gross thickness, water saturation, permeability and shale volume content. These are very crucial that they are used as input data for reservoir characterization. Incidentally, the Agbada Formation is host to the hydrocarbons accumulations in the subsurface formation in Niger Delta region.

One of the earliest studies of the relationship between log responses and the physical properties of the rock was a pioneer work by [2] in which he showed that the electrical resistivity log is useful in determining certain reservoir characteristics. Reference [3] showed various methods of formation evaluation of hydrocarbon reserves in Nigeria, most of which are based on logs couple with core sample as well as wireline formation tests. Studies on the clay distribution development trend have been applied to illuminate the behaviour of reservoirs. The log responses of different clay distribution patterns in reservoir have been studied and show that detrital clays such as structural and laminated clays generate similar log responses on thick shale beds, hence a shally-sand equation is developed that requires shale-resistivity value to be used. On similar studies, reference [3] described three common distribution patterns of clay heterogeneity observed in reservoirs, namely; structural, laminated and dispersed clays each exhibiting different effects on reservoir properties. Conversely, although laminated clays are usually thinner than the interbeded sandstones, there is usually a disproportionate change in resistivity and porosity arising from these clays not commensurate to their thickness in a proportion comparable to that of structural clays [4]. Reference [5] described the significant impact which dispersed clays can have on reservoir's producibility. In the latter's view, a given quantity of pore-filling clay has more debilitating effect on the permeability of sandstone than the same quantity in a laminated shale lamina interlaminated between clean sandstone bed. According to him, a clean sandstone with a good porosity of value of $30 \%$ can have the porosity reduced to $0 \%$ if the pore spaces of the sandstone are clogged by dispersed clay, but if the clay/shale is a lamina only within the clean sandstone, about two-thirds of the permeability could be retained. Reference [6] identified growth fault and rollover anticline as the major petroleum 
traps in the Niger Delta. He described them as arising from compressional uplift very close to the slope and having extensional growth faults which were developed on the modern shelf and slope.

Reference [7] characterized the reservoirs of "Paradise Field" from well logs data. They suggested that with good structural and stratigraphic traps basin ward, the offshore depobelt holds better prospect for the Paradise field (Niger Delta). They concluded that the reservoirs for the discovered hydrocarbons are sandstones within the Agbada Formation, while the reservoirs for undiscovered petroleum below currently producing intervals in the distal portions of the delta system may include turbidite sands within the Akata. Reference [8] used the combination of density and neutron responses to estimate shale volume and found out that is often more accurate than estimating Vsh from single log measurement. In the study, it was found out that a volume of shale in laminar mode may prove helpful in reducing water coning while the same amount of shale in dispersed mode may influence permeability significantly and reduce production. Reference [9] carried out a detailed formation evaluation of an appraisal well in the "Green field" onshore Niger Delta. Reference [10] evaluated the effects of clay heterogeneity on reservoir properties. However, this research uses open-hole logs to evaluate petrophysical parameters of the successions penetrated by the four wells in the Dulga field, onshore Niger Delta. Reference [11] employed an integrated interpretation of seismic and well log data over "Y" field in the Niger Delta area of Nigeria with the aim of characterizing reservoir rocks using quantitative seismic attributes and petrophysical properties. The maximum and RMS attributes were used to characterize three reservoirs. They concluded that seismic attributes could be used to predict and characterize reservoir rock properties. References [12] and [13] assessed the heterogeneity and petrophysical evaluation of reservoirs in the "Akbar Field", Niger Delta Nigeria. They found out that reservoir qualities of the reservoirs are rarely affected negatively despite the occurrence of the three clay types. They noted that "inasmuch as the horizontal fluid flow may not have been affected due to good porosity, the vertical flow could be impaired as a result of the presence of numerous laminated clay/shale baffles compartmentalizing the reservoirs". Furthermore, they concluded that well logs could be used as an alternative to core data in determining the clay distribution trend sands and the degree of their negative effects of their reservoir qualities. Reference [14] studied the effects of shale volume distribution on the elastic properties of reservoirs in Nan tin Field Offshore Niger Delta. Reference [15] successfully evaluated the hydrocarbon reservoirs rocks containing shale streaks in the eastern Niger Delta basin using geophysical well logs.

However as accurate delineation and development of reservoirs become very necessary coupled with high cost of hydrocarbon production in the Costal Swamp Niger delta, there is need to properly characterize reservoirs from old and producing fields. The knowledge of petrophysical properties such as porosity, permeability, net pay and net thickness is required for accurate simulation of 
field performance. Such information about the reservoir will help improve production rates, rejuvenate old depleting oil fields, predict future reservoir performance, minimize cost and help management of oil companies draw up accurate financial models. Usually, the deposition of clastic sandstone reservoirs seldom occur alone, they occur alongside finer clay minerals which are often of varying morphology and distribution pattern. Such clay minerals significantly affect important reservoir properties such as porosity, water saturation and permeability.

Local documentation or published works on "CAC-field" appears scarce except for the documentations of individual prospecting companies in the study area. Therefore, it becomes paramount that complete evaluation of reservoir of interest must be done while exploring for hydrocarbon in Niger Delta. This will help recover bypassed hydrocarbons from old and producing fields and thereby maximizing yield and boosting the country's economy. Hence, the objectives of this study include reservoirs correlation, detailed characterization of reservoirs using their petrophysical properties, clay distribution patterns determination and their effects within delineated reservoirs in "CAC-field", Costal Swamp, Niger Delta.

\section{Geology of Study Area (Niger Delta, Nigeria)}

The Niger Delta basin also called the Niger Delta province is situated on the continental margin of the Gulf of Guinea between latitude $3^{\circ} \mathrm{N}$ and $6^{\circ} \mathrm{N}$ and longitude $5^{\circ} \mathrm{E}$ and $8^{\circ} \mathrm{E}$. The Niger Delta is ranked one of the world's major hydrocarbon province with an area of $300,000 \mathrm{~km}^{2}$ [16] and the most important in the West African continental margins [17]. The $12 \mathrm{~km}$ thick Niger Delta clastic contains the $12^{\text {th }}$ largest known accumulations of recoverable hydrocarbon with reserve exceeding 34 barrels of oil and 93 trillion cubic feet of gas [17]. The basin has been identified to contain only one petroleum system referred to as the Tertiary Niger Delta petroleum system [18]. Detailed investigation has been carried out in the Niger Delta basin for the past decades because of its economic importance. The Niger Delta geology systems: structural and stratigraphic setting, including its petroleum system, have been investigated and summarized by some earliest researchers. Notable among them are [19]-[26] and several others. Reference [24] noted that both major and minor structures characterized the region till present. These structures are simple non-faulted anticline rollover structures, faulted rollover anticline with multiple growth fault and complicated collapse crest structures. References [6] and [16] identified only one petroleum system in the Niger Delta known as the Tertiary Niger Delta (Akata-Agbada) Petroleum system. Reference [27] reviewed the Niger Delta hydrocarbon habitat in his report. Majority of the petroleum is sourced from the Akata Formation while the Agbada Formation serves as the reservoir rocks. The maximum extent of the petroleum system coincides with the boundaries of the province while the minimum extent is defined by the areal extent of fields and contains known resources of 34.5 billion barrels of oil (BBO) and 93.8 trillion cubic feet of gas (TCFG) 
[28]. Reference [29] also showed that the petroleum traps were mainly of growth faults. Reference [30] showed that variations in composition with depth and product of migration and not source rock organic matter input or thermal maturity; buoyancy is the driving force for migration of hydrocarbons, while [31] observed that the mode of hydrocarbon trapping in the Niger Delta is a combination of structural and stratigraphic trapping. They also maintained that Opuama sedimentary infill forms part of the Niger Delta stratigraphic succession and exhibits itself as a clay plug set within the paralic Agbada Formation.

The stratigraphy of the Niger Delta is a direct product of the various depositional processes prevalent in the area and comprises an upward coarsening regressive association of Tertiary clastics up to $12 \mathrm{~km}$ thick. The delta displays a concentric arrangement of terrestrial and transitional depositional environment [32]. In Niger Delta, as in many delta areas, it is very difficult to define a stratigraphic nomenclature. The occurrences of small number of differing lithologies make it almost impossible to define units and boundaries succinctly to constitute separate formations in a formal sense. However, evidence from all the deep wells in the Niger Delta shows three lithostratigraphic successions in which a regressive sequence is properly defined [33] (Figure 1).

Reference [19], divided the Tertiary deltaic complex into 3 major facies on the basis of the dominant prevailing environmental. The major depositional characteristics include marine, paralic and continental environments.

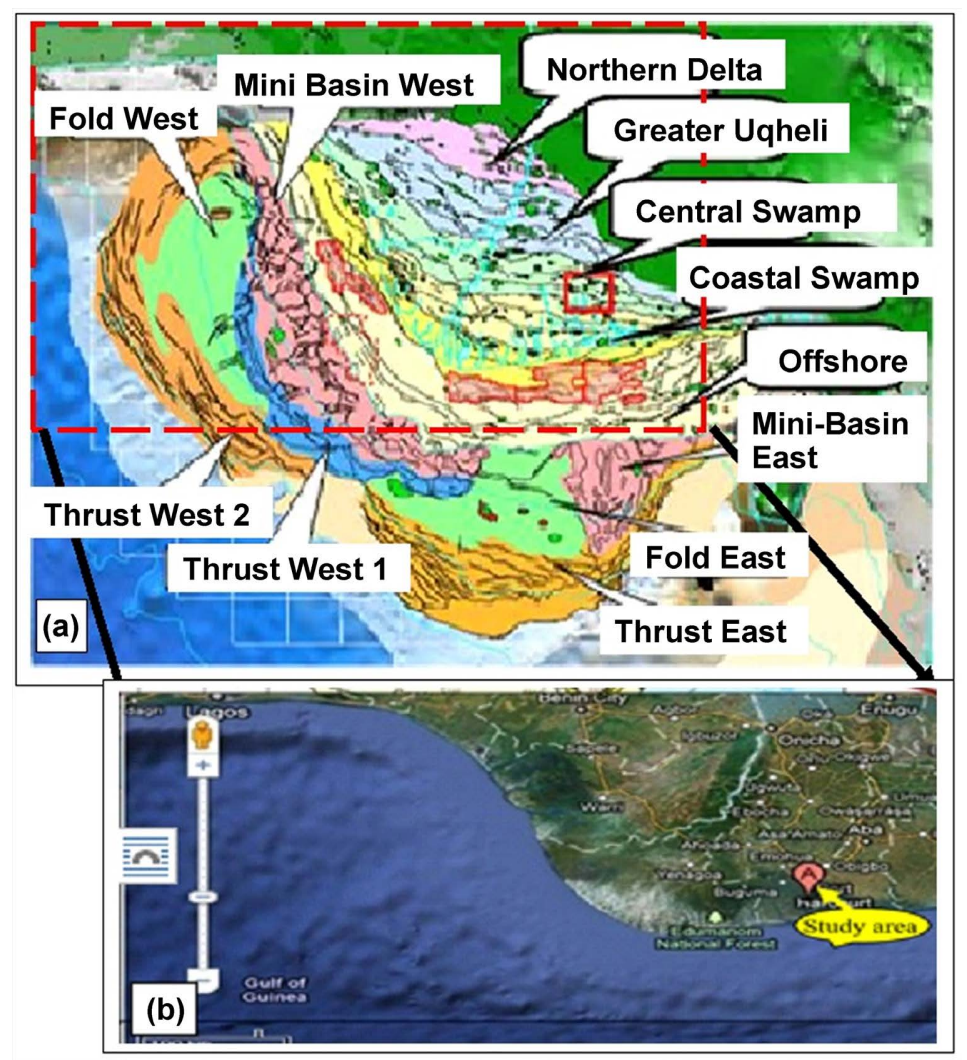

Figure 1. (a \& b) Outline Map of the Study Area (Modified from [33]). 
1) Marine shales/claystones of variable thickness occupying the deepest part of the Niger Delta basin, designated as the Akata Formation.

2) A paralic deposit consisting of alteration of sandstones, silt stones and claystones at the middle of the basin, with the shaliness increasing with depth until it grades into the majorly undercompacted shales of the underling formation. This is known as Agbada Formation.

Continental/Alluvial sands at the top known as the Benin Formation.

\section{Materials and Method of Study}

The dataset for the study includes, pre-stack 3D seismic data; well log and checkshot, The detail of the well logs used is shown in Table 1. The software used include: Interactive Petrophysics, ArcGIS, and Petrel. This study involves the use of wireline logs, checkshots, deviation and 3D pre-stack seismic data. The Interactive Petrophysics and the Petrel software were employed for the analyses; These were obtained from Oil company (Shell Petroleum Development Co. Ltd), operating in the Niger Delta. This was facilitated through the Department of Petroleum Resources.

The co-ordintates of the exact location is not revealed for proprietary reasons, the survey inline is 55,000 to 5891 and crossline is 1480 - 1720 as shown in Figure 2.

The hydrocarbon reservoirs were revealed from the structural architecture interpreted from the seismic data using the reflection and termination patterns and supported by the study of the direct hydrocarbon indicator. To establish good well correlation and reservoir continuity across the field, a suite of petrophysical logs were taken from 4 wells, namely, gamma ray, resistivity, spontaneous potential, density and neutron.

Well logs data were imported into the software, namely, the Interactive Petrophysics (IP) and Petrel software. Identification of lithology and well correlation

Table 1. Well information quality check list.

\begin{tabular}{ccccc}
\hline WELL & CAC1 & CAC2 & CAC3 & CAC4 \\
\hline DEPTH $(\mathrm{m})$ & 4335 & 3975 & 4370 & 4450 \\
Gamma Ray & $\sqrt{ }$ & $\sqrt{ }$ & $\sqrt{ }$ & $\sqrt{ }$ \\
Resistivity log & $\sqrt{ }$ & $\sqrt{ }$ & $\sqrt{ }$ & $\sqrt{ }$ \\
Spontaneous Potential Log & $\sqrt{ }$ & $\sqrt{ }$ & $\sqrt{ }$ & $\sqrt{ }$ \\
Density Log & $\sqrt{ }$ & $\sqrt{ }$ & $\sqrt{ }$ & $\sqrt{ }$ \\
Neutron log & $\sqrt{ }$ & $\sqrt{ }$ & $\sqrt{ }$ \\
Spectral Gamma ray log & $\sqrt{ }$ & $\sqrt{ }$ & $\sqrt{ }$ & $\sqrt{ }$ \\
Checkshot data & $\sqrt{ }$ & $\sqrt{ }$ & $\sqrt{ }$ \\
Deviation log & $\mathrm{X}$ & $\mathrm{X}$ & $\mathrm{X}$ & $\sqrt{ }$ \\
\hline
\end{tabular}

KEY: $\sqrt{ }=$ Present; $\mathrm{X}=$ Absent. 


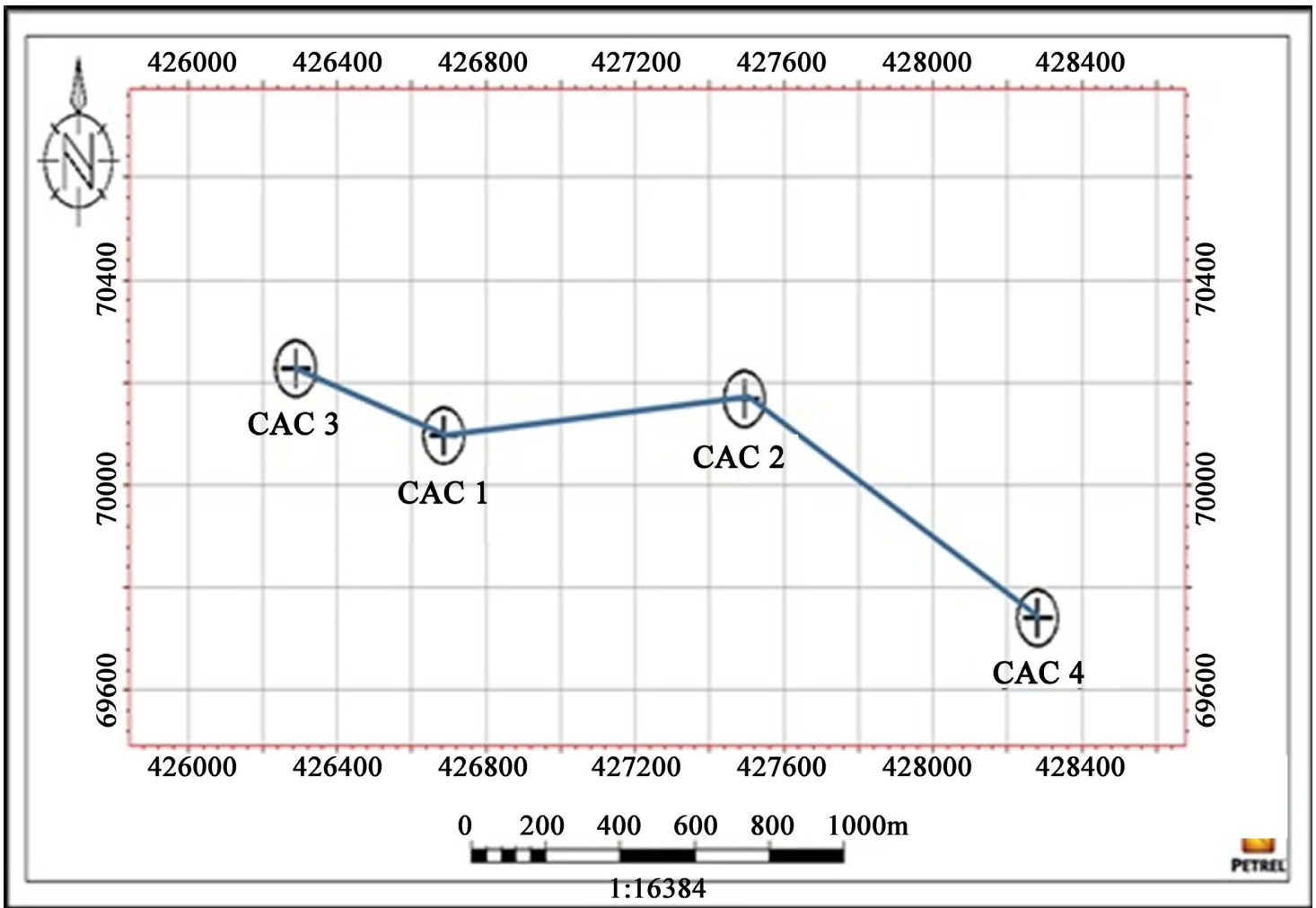

Figure 2. Well locations and distribution across the study area.

were analyzed on Petrel. Petrophysical evaluation of the wells was done using the Interactive Petrophysics software. Arc GIS was used in generating some of the maps of the study area and its surroundings.

Seismic interpretation was carried out starting with seismic to well ties. This was performed to merge the 2 datasets acquired in 2 different units, the seismic (in time) and well log in (depth). This helped to validate the location and correspondence of the reflections on the seismic (horizons) by tying them with the position on the well data (sand tops). A combination of density, sonic/checkshot was used primarily for this function. In addition other data employed to constrain/quality check the results included gamma ray, resistivity, neutron and calliper logs. Hence the synthetic seismogram was for seismic to well integration which helped in mapping the delineated hydrocarbon bearing reservoirs on the seismic data. Figure 3 is a display of the seismic to well tie panel.

Following the well-to-seismic match, the reservoirs were delineated on the seismic as well as the faults. The faults were mostly listric faults. Reservoir tops were delineated and correlated across the wells and their corresponding horizons mapped on seismic throughout the study area. A total of four horizons known as RES 1, RES 2, RES 3 and RES 4 were mapped. These horizons were picked corresponded to the top of sands from the gamma ray logs. Figure 4 shows detail of the target horizons interpreted in the field.

The thicknesses of the reservoirs were determined using the cut-offs from gamma ray and resistivity logs from the hydrocarbon bearing units of the logs 


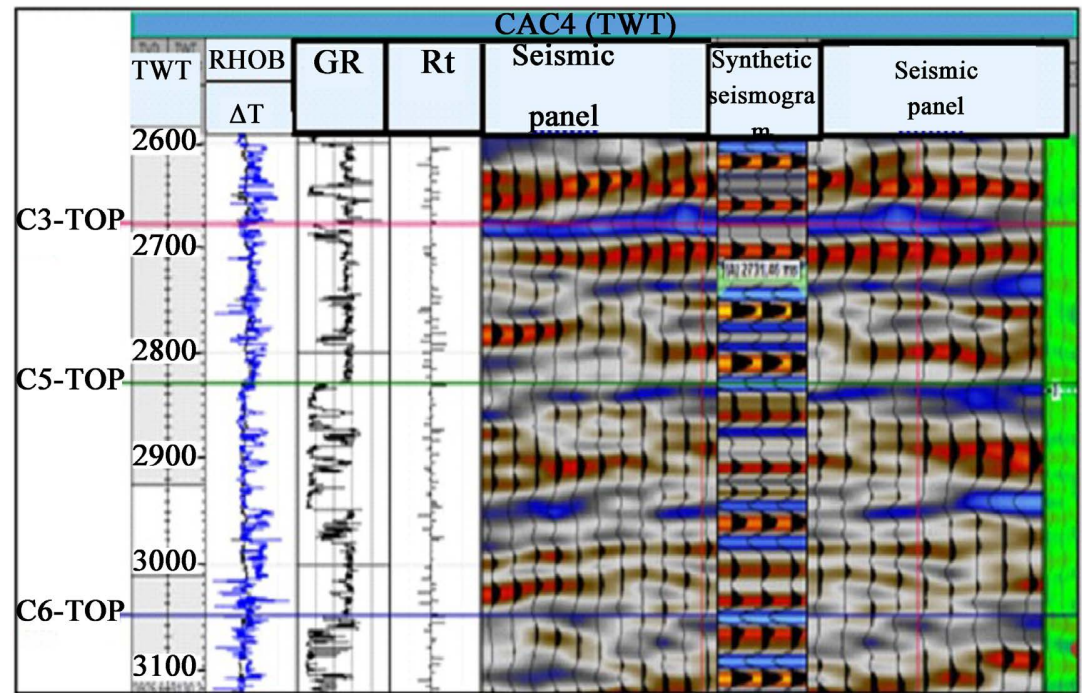

Figure 3. Synthetic seismogram showing high correlation between seismic and stratigraphy.

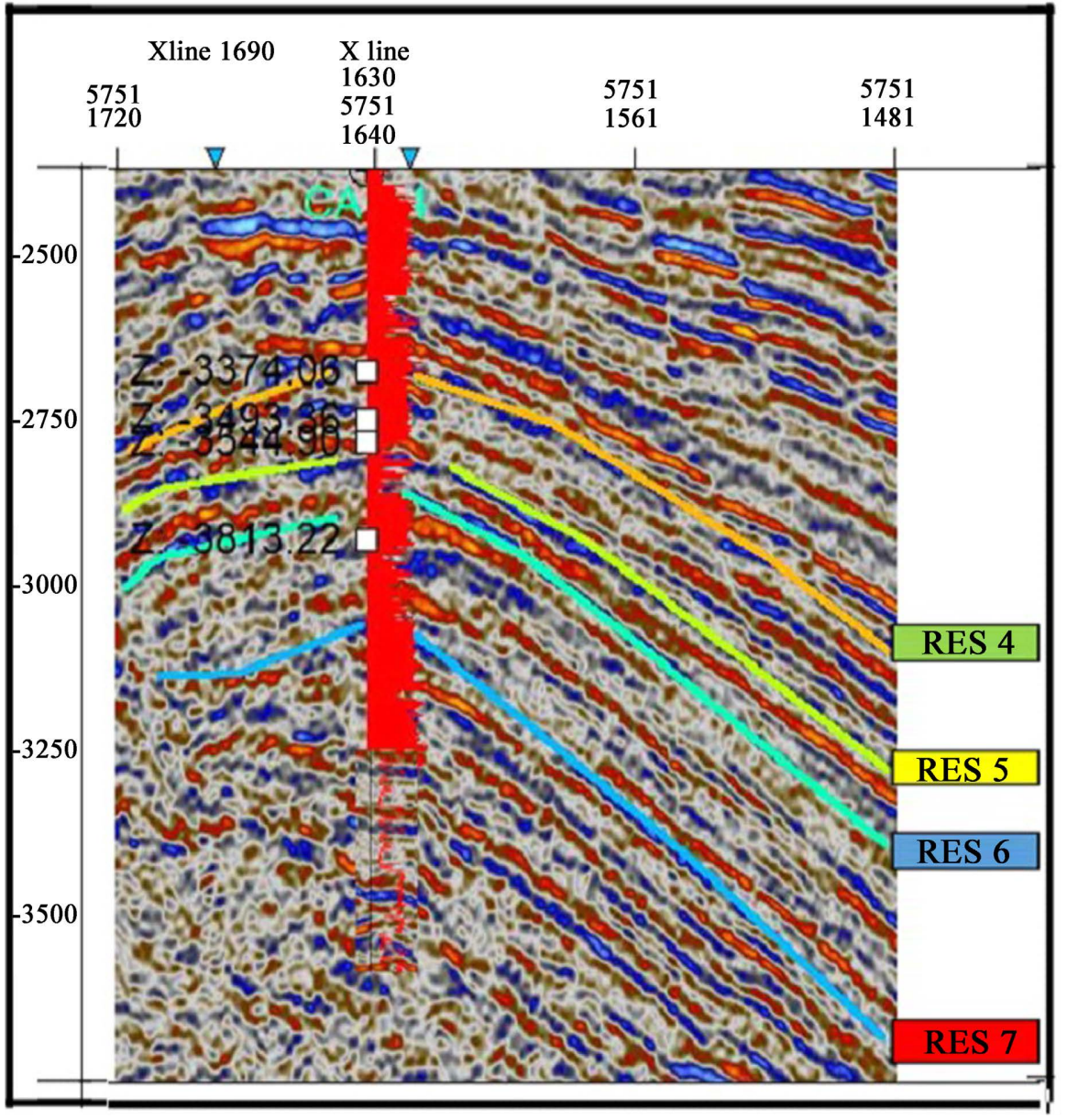

Figure 4. Section on seismic cross-line showing the overlain GR $\log$ of CAC 4 used as a guide to map horizons on seismic.

from the individual wells and subsequent correlation across the wells provided in the field. Due to the high resistivity of hydrocarbon and low resistivity of wa- 
ter, the values of resistivity thus is a good hydrocarbon indicator at reservoir scale, hence it is easy to discriminate hydrocarbon bearing from water bearing intervals. The principle of density differential among the different state of the hydrocarbon (liquid or gas), was utilized in the application of Neutron and Density tools in discriminating the type of hydrocarbon present. Also at some points where gamma ray log fails to differentiate reservoir rocks (sands) from non-reservoir rock (shales), it was integrated with spontaneous potential and resistivity log for better lithological identification, hence making correlation much easier. This is shown at depth intervals $3683 \mathrm{~m}$ (RES_5 base) and $3737 \mathrm{~m}$ (RES_6 top) where the gamma ray logs values suggest lithology to be sand whereas it is shale from the Spectral gamma ray and Neutron-density logs. Figure 5 shows the gamma ray logs showing the distribution of sand and shale at CAC-3 reservoir.

Petrophysical analysis of the well logs was done by providing information about the net-to-gross volume, average porosity, average permeability, water saturation, hydrocarbon saturation and average volume of clay. Clay distribution patterns were delineated by plotting clay volume against porosity values in order to evaluate the influence of shale on reservoir properties.

\section{Evaluation of Petrophysical Properties}

Petrophysical parameters of the hydrocarbon bearing zones were estimated from well logs using Interactive Petrophysics software. This also involved the use of empirical formulae to determine the petrophysical parameters such as volume of shale, net-to-gross, porosity, permeability, water saturation etc. The shale volume

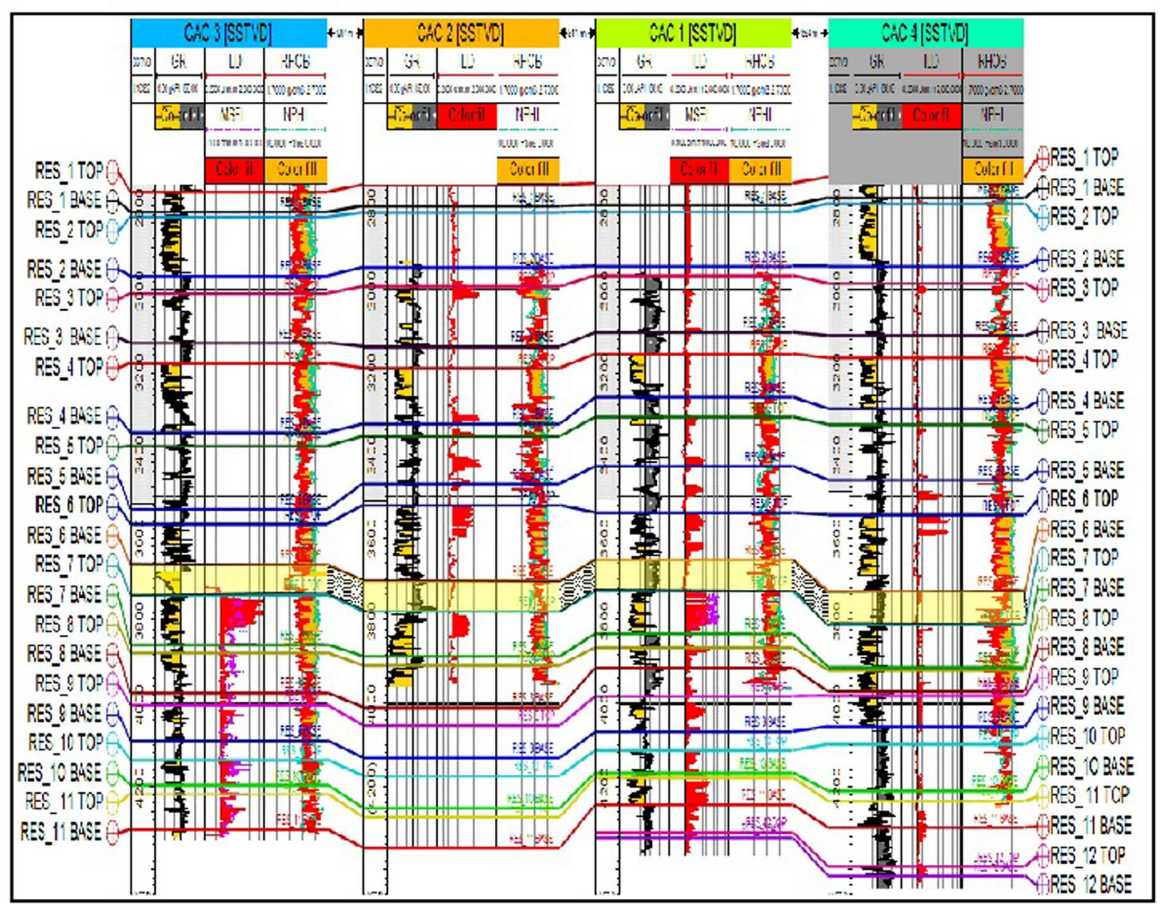

Figure 5. Gamma ray logs showing shale interval (highlighted) as sand in CAC-3. 
versus effective porosity cross plot enabled the estimation of the shale distribution patterns present in the reservoir and as well as their effects in the reservoir.

To determine the Formation porosity $(\phi)$, the bulk density reading obtained from the reservoir interval was substituted in Equation (1), given the relationship with the matrix density $\left(p_{m a}\right)$ and formation fluid densities $\left(p_{f}\right)$. To estimate the formation porosity the log formation bulk density $\left(p_{b}\right)$ value of each reservoir was substituted in Equation (1): [34].

$$
\phi=\frac{p_{m a}-p_{b}}{p_{m a}-p_{f}}
$$

Similarly, for each depth interval, the Effective porosity $(\phi)$ was computed from the relational model in Equation (2) thus: $p_{m a}$

$$
V_{s h}=\frac{p_{m a}-p_{s h}}{p_{m a}-p_{f}}
$$

where;

$$
\begin{aligned}
& \phi=\text { porosity from density log, } \\
& p_{m a}=\text { matrix density }(2.65 \mathrm{~g} / \mathrm{cc} \text { for sandstone }), \\
& p_{f}=\text { formation fluid density }(1.0 \mathrm{gm} / \mathrm{cc} \text { for water and } 0.8 \mathrm{~g} / \mathrm{cc} \text { for hydrocar- }
\end{aligned}
$$
bon),

$$
p_{b}=\text { formation bulk density (obtain from density log at } 0.5 \mathrm{ft} \text {. interval), }
$$$$
p_{s h}=\text { density of adjacent shale body. }
$$

Ideally a typical hydrocarbon reservoir contains the 3 components, gas, Oil and water in that stratification order, with lower water content indicating higher hydrocarbon. Therefore estimating the amount of water saturation is key in quantifying the amount of hydrocarbon in place, while the resistivity log identifies the hydrocarbon column above the fluid contacts. The net to gross provided by the gamma ray log together with the porosity is combined to compute the amount of hydrocarbon in place. Water saturation was estimated using the relationship between the resistivity of formation water and porosity as shown in the empirical relationship in Equation (3):

$$
\begin{aligned}
& S_{w}=\frac{a \times R_{w}}{\phi^{m}}, \\
& S_{h}=1-S_{w}
\end{aligned}
$$

where;

$S_{W}=$ water saturation of the uninvaded zone,

$S_{h}=$ water saturation,

$R_{t}=$ true formation resistivity (from ILD log curve),

$\phi=$ porosity values obtained from a porosity log,

$R_{W}=$ resistivity of formation water.

Permeability is a measure of the ease of passage of fluid in a medium as a result of the presence of interconnecting pores within it. In rocks, especially sandstones, this is controlled by the interconnectivity of the matrix and degree of cleanliness in terms of clay content. Permeability value for the delineated reser- 
voir is calculated using the [35]'s empirical relationship (Equation (4)).

$$
k=\left[\frac{250 \times \phi^{3}}{S_{\text {wirr }}}\right]^{2}
$$

where $\phi$ is effective porosity, and $S_{\text {wirr }}$ is the irreducible water saturation.

The Gross reservoir thickness is the total interval of the region recognized as the reservoir interval, including regions occupied by sandstone and clays within the reservoir. This thickness is determined by identifying interval covering both sand and shale within the reservoir zone under study using gamma ray log and recorded depth values. Net sand thickness, on the other hand, is the interval of the reservoir occupied by sand alone. The net sand thickness was determined by subtracting the thickness of shale/clay baffle within a reservoir thickness. The expressions used for mapping out interval thicknesses in the wells studied are shown as follows.

GST $=$ Gross sand thickness (Base of sand - Top of sand).

NST $=$ Net sand thickness (Base + top of sand - Thickness of shale baffle).

Therefore Net to gross is estimated from Equation (5).

$$
\mathrm{NTG}=\frac{\mathrm{NST}}{\mathrm{GST}}
$$

\section{Clay Distribution Pattern Prediction}

The elastic properties of heterogeneous reservoirs are affected by the clay contents and their distribution within the quartz grain. A good prediction pattern of shale/clay heterogeneity in hydrocarbon reservoirs help to precisely evaluate associated petrophysical properties such as water saturation, porosity and permeability. This evaluation is very crucial as it is key assessing the viability or otherwise of the field in terms of hydrocarbon potential, hence guides management decision making on investment in the field development.

\section{Results and Discussion}

Well correlation was carried out along a strike direction and multiple dip direction as shown in Figure 6 and Figure 7 respectively with two main lithologies of sandstone and shale identified. Twelve (12) reservoirs pseudo-named, RES1RES12, were delineated and correlated in each of the wells except in CAC-1 where RES 1 and 2 were missing. RES 1, 2, 8, 9, 10, 11, 12 were also missing in CAC-3 while RES 12 was not observed in CAC-3. The extent of the reservoirs were laterally equivalent at the top of the correlation panel but became structurally controlled towards the base (Figure 5). Also at the shallow and middle portions of the reservoir sandiness becomes greater with increasing thickness Figure 6 is a well log correlation panel showing stacking patterns and reservoirs of interest for petrophysical evaluation (multiple dip section). Figure 7 shows a multiple dip section of Focus reservoirs distribution (highlighted in red colour) across the 4 wells.

Figures 8-11 show the result of the estimated petrophysical parameters of the 


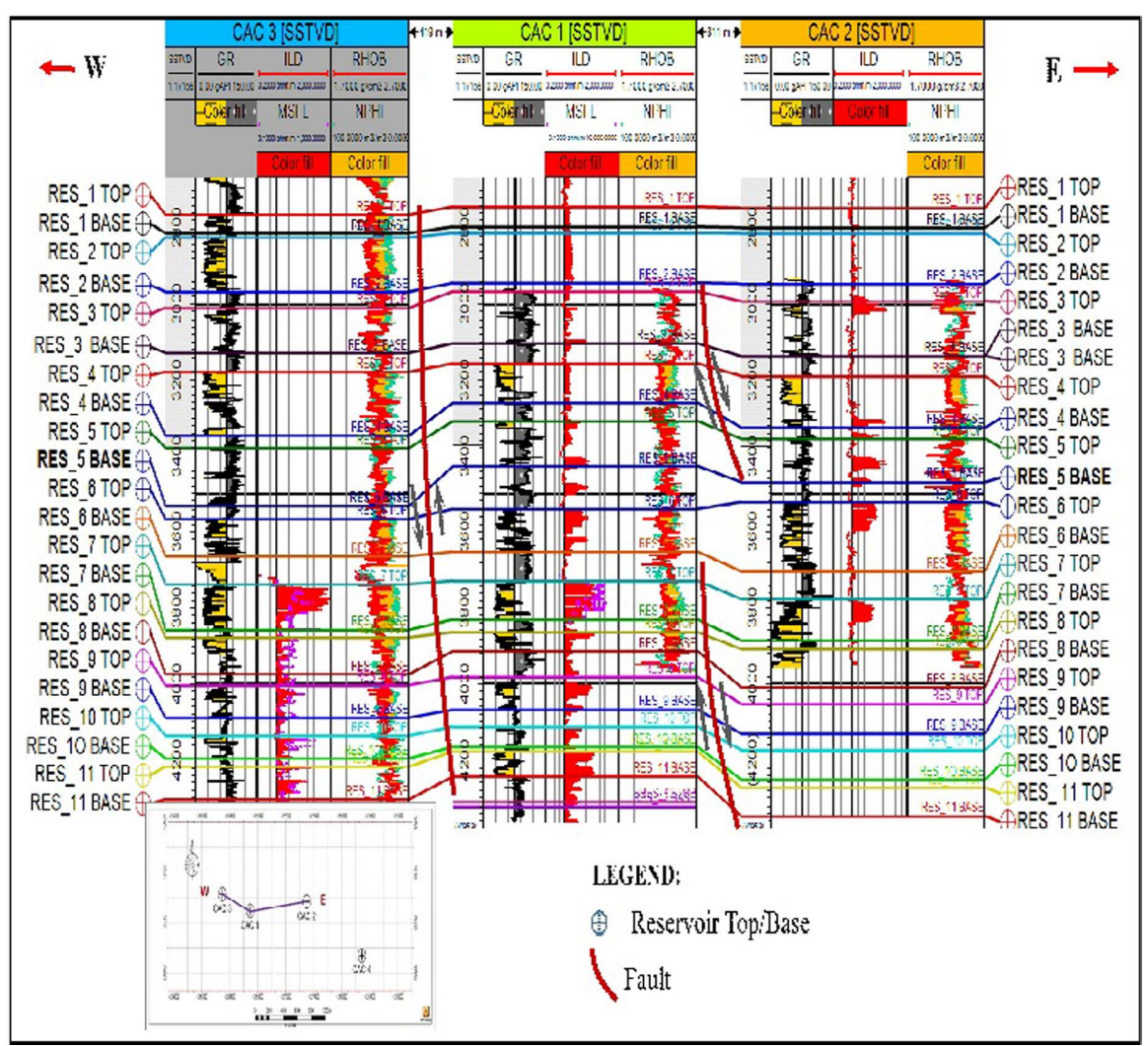

Figure 6. Well log correlation along strike direction.

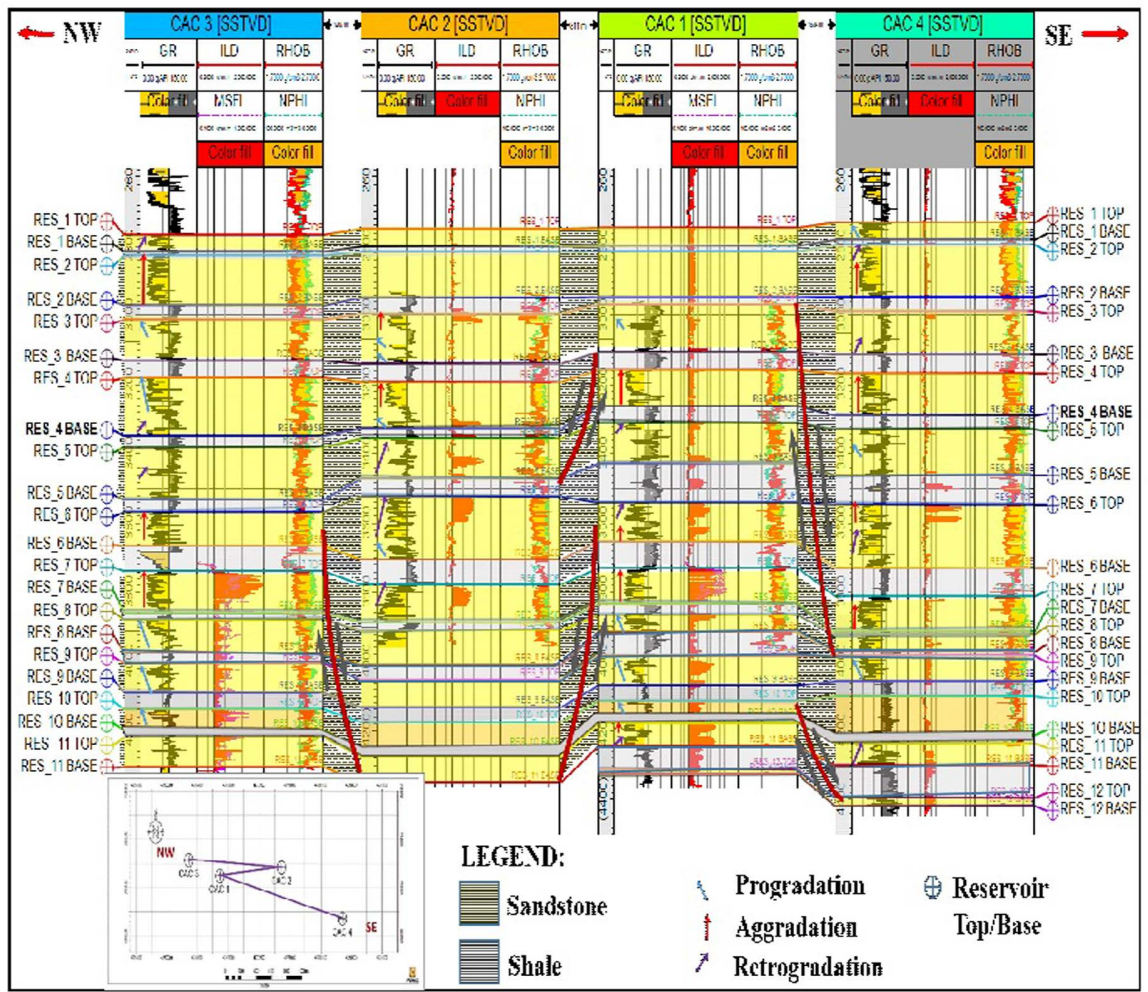

Figure 7. Multiple dip section of Focus reservoirs distribution (highlighted in red colour) across the 4 wells. 


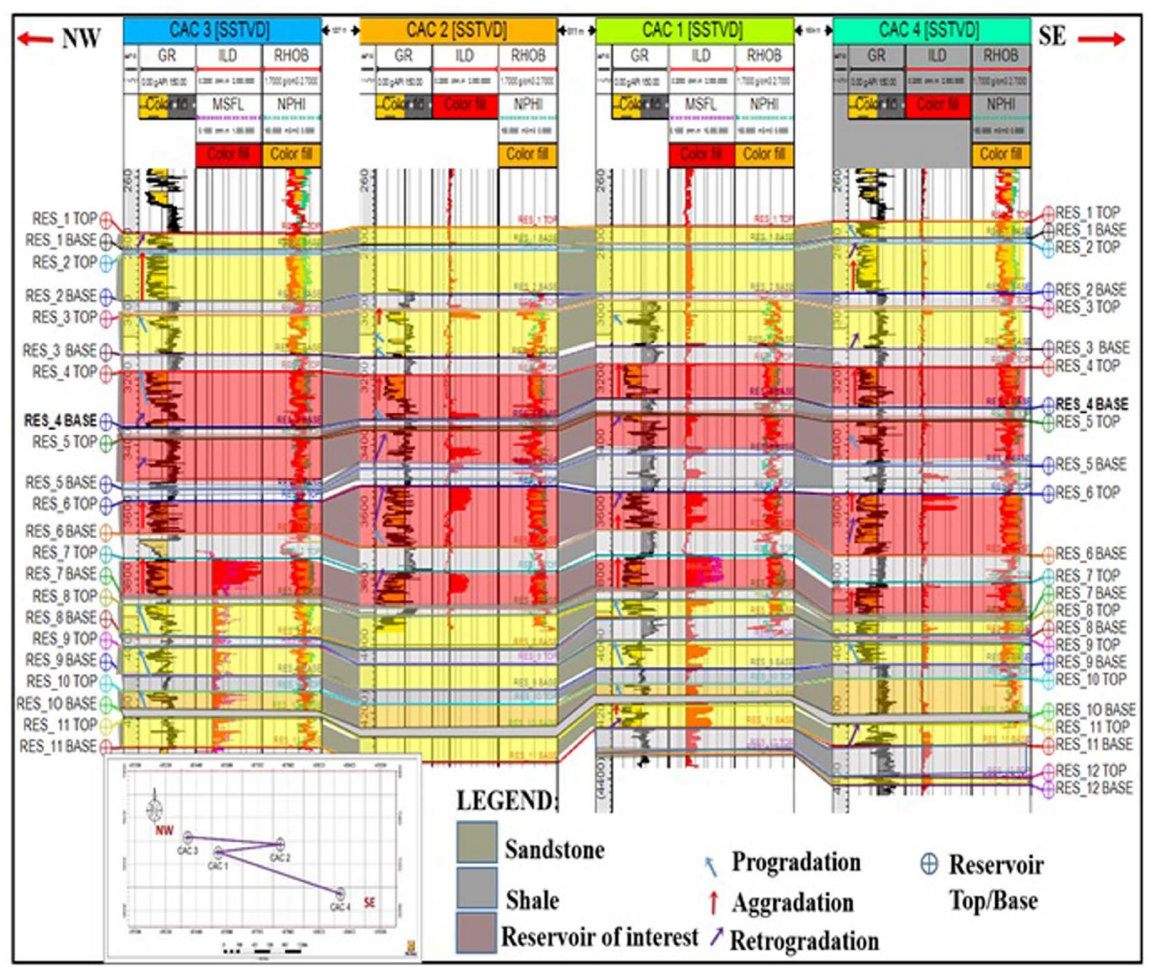

Figure 8. Well log correlation panel at multiple dip section showing stacking patterns and reservoirs of interest for petrophysical evaluation.

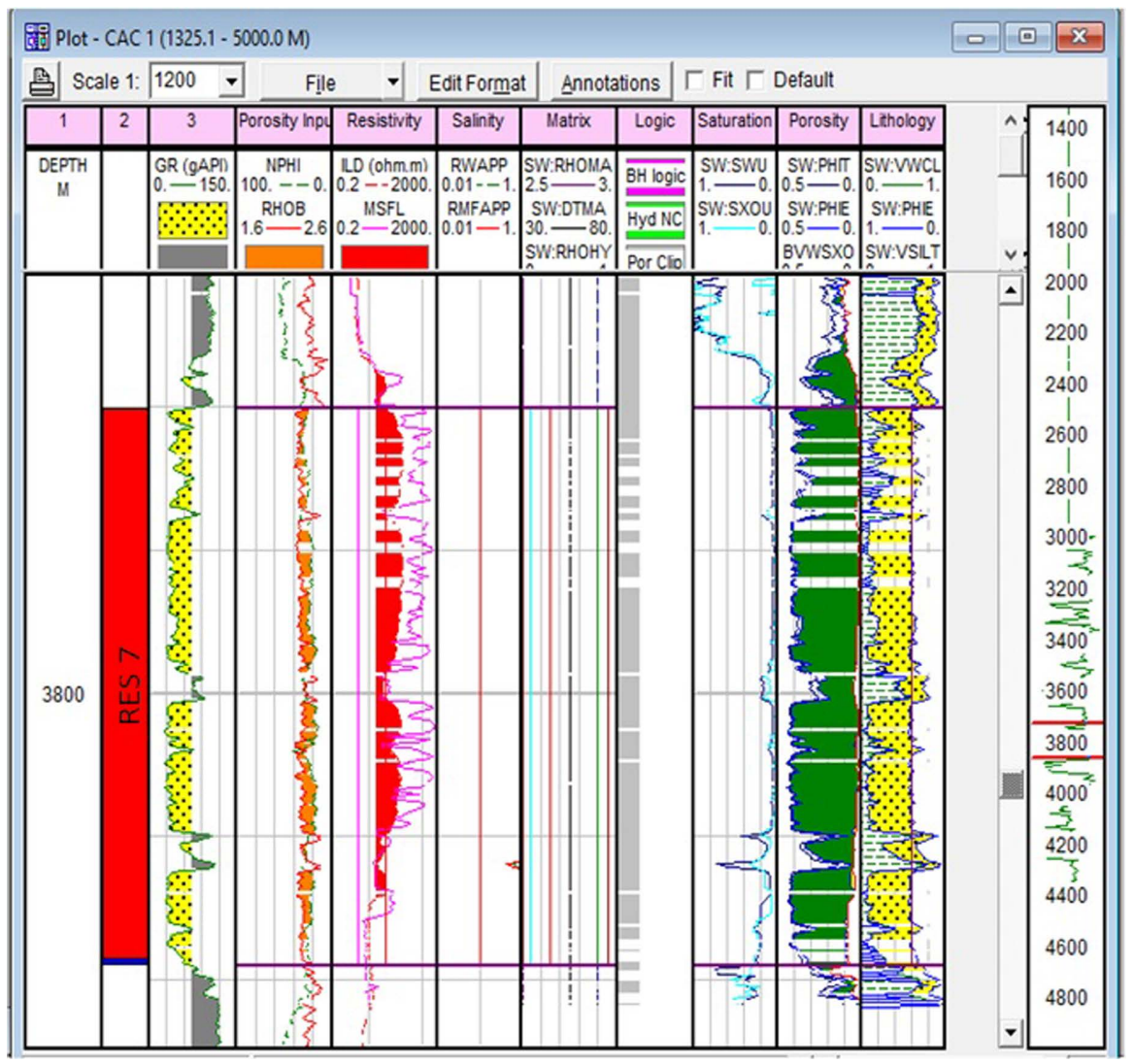

Figure 9. WELL CAC-1 with corresponding petrophysical results of target reservoir. 


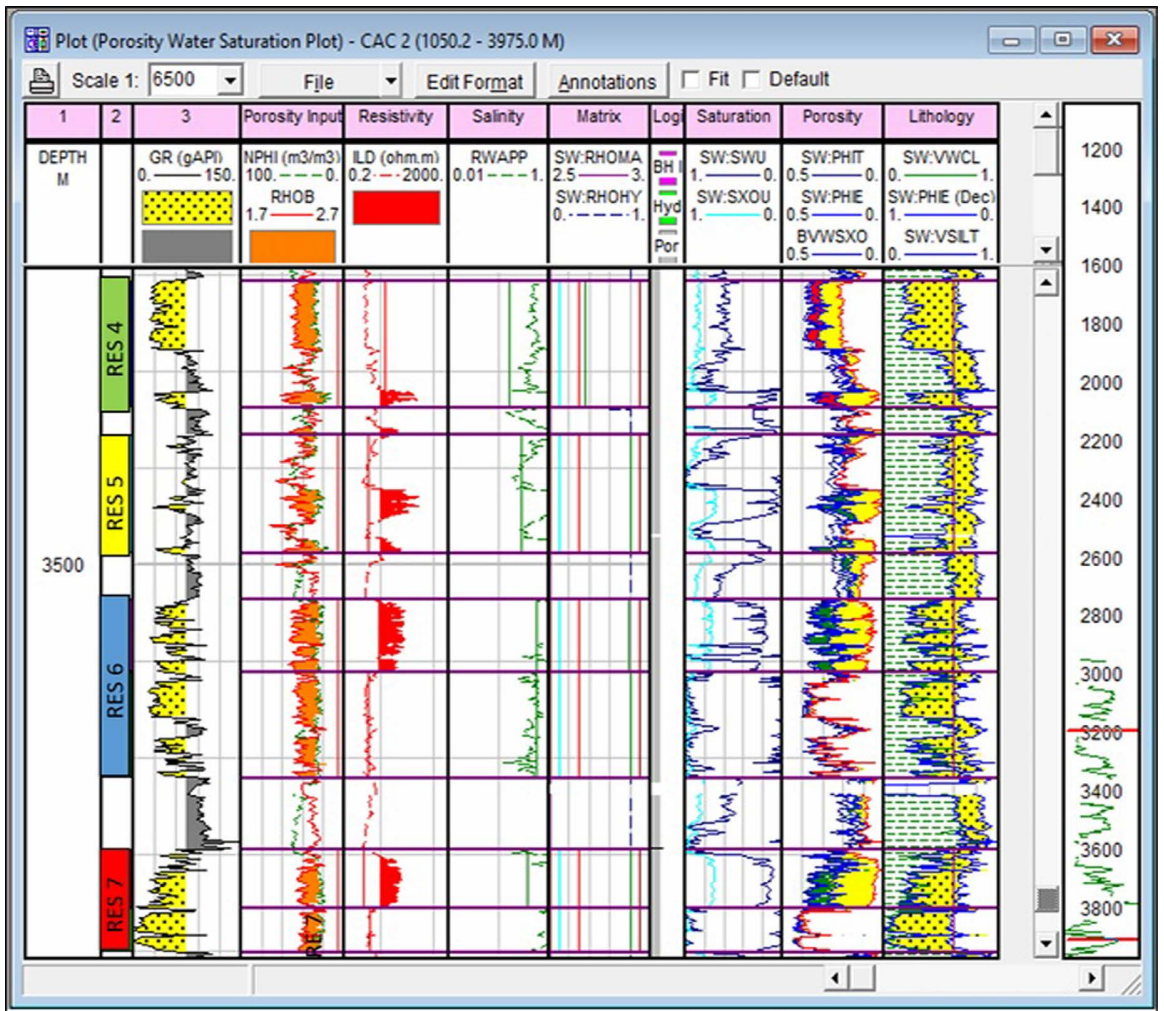

Figure 10. Well (CAC 2) with corresponding petrophysical results of target reservoir properties.

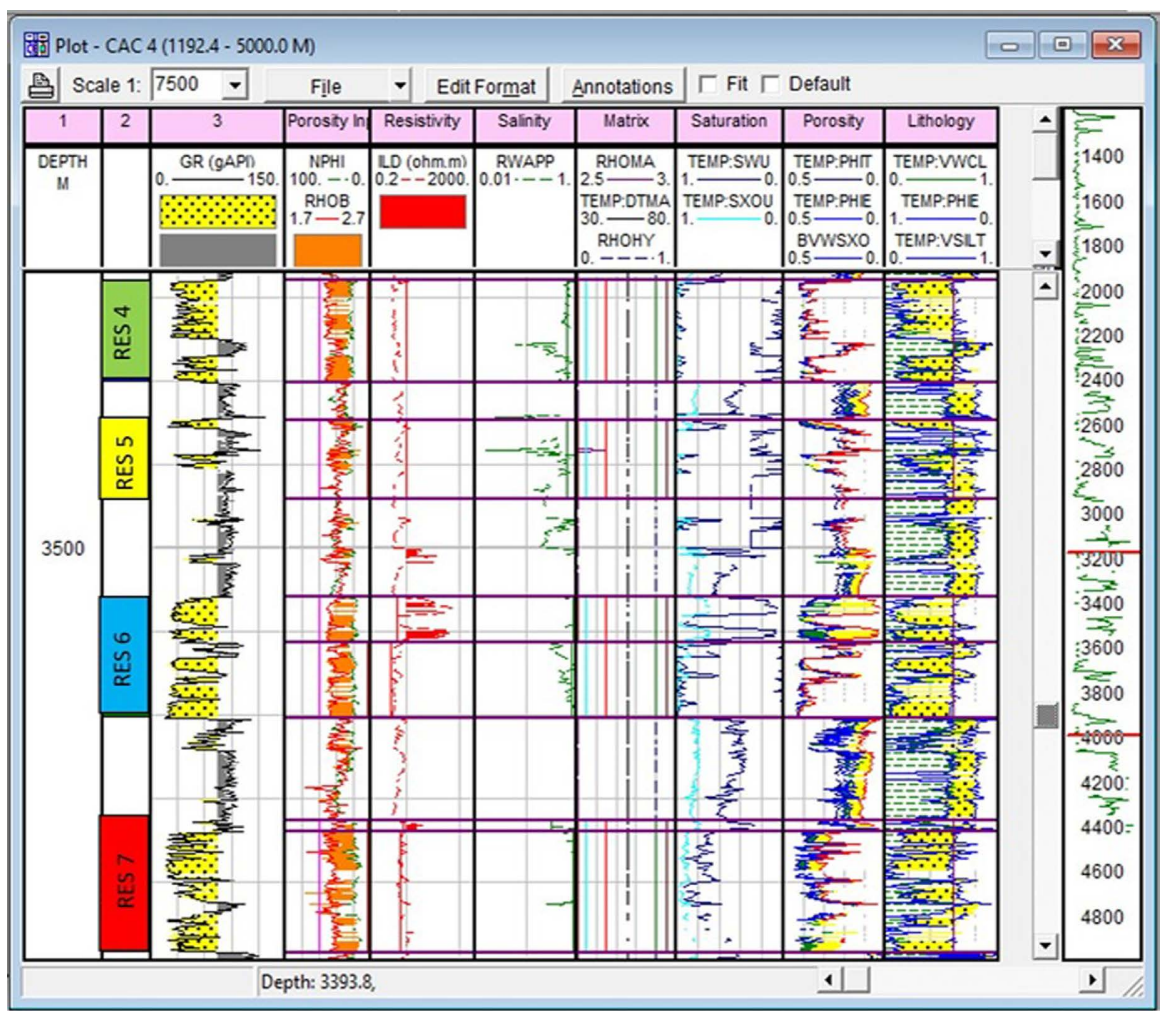

Figure 11. CAC 3 WELL with corresponding petrophysical results of target reservoir properties. 


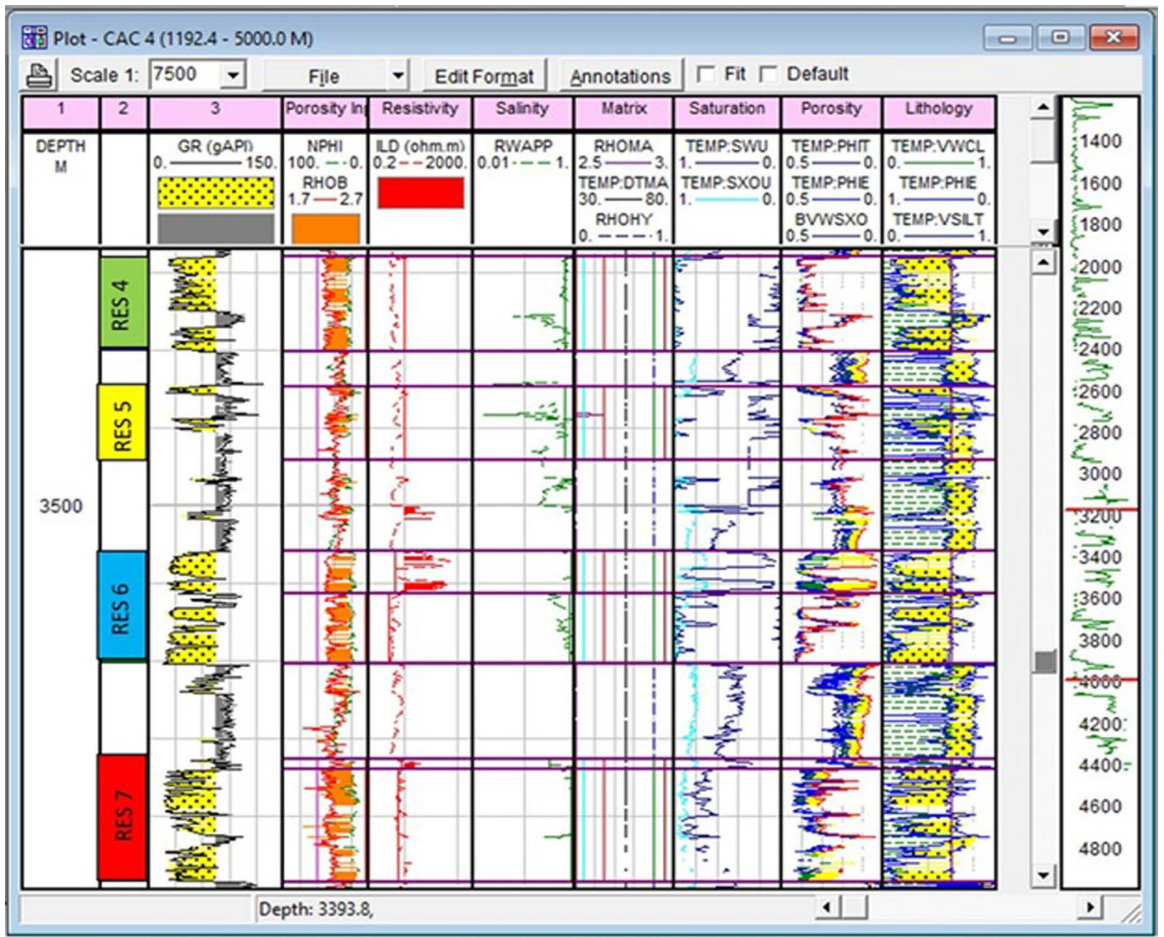

Figure 12. WELL (CAC 4) with corresponding petrophysical results of target reservoir properties.

reservoir such as porosity, water saturation, and net to gross. The implication of the occurrence or dominance of each shale pattern thus provides a good basis for establishing the influence of shale on each on the reservoirs under study. This in turn helped to determine the economic viability or otherwise of the field. The petrophysical parameters as well as the shale distribution pattern play key role in the reservoir quality and performance. A dispersed shale will have an adverse effect on the porosity and permeability of the reservoirs as it tends to block the pore throats unlike the laminated and structural shale that have little or minimal effect.

The results from evaluation of the above log parameter indicate that of the 12 reservoirs delineated, only 4 have hydrocarbon accumulation. Variation in porosity and permeability values were observed throughout the reservoirs and are attributed to the shale distribution patterns present. Effective porosity against shale value crossplots for the 2 well is shown in the following Figures 13-15.

A porosity average of $21 \%$ was computed across all wells in RES4. $17 \%$ in CAC-2 as well as $25 \%$ in CAC- 4 . The average values of permeability are $938 \mathrm{mD}$ and $2406.49 \mathrm{mD}$ for CAC-2 and CAC-4 respectively (Table 2). This shows a very good porosity and permeability values which are high enough to allow movement of fluid within the designated reservoirs. The clay values are 14 and $15 \%$ which is below the value at which clay bound water affects resistivity and water saturation values (Hilchie, 1978) [35]. The average Water and Hydrocarbon saturations for the reservoirs are $47 \%$ and $53 \%$ respectively. In Figure 13 , the cross plot of clay volume against porosity showing prevalent shale distribution 
Table 2. Result of the Petrophysical analysis of "RES 4".

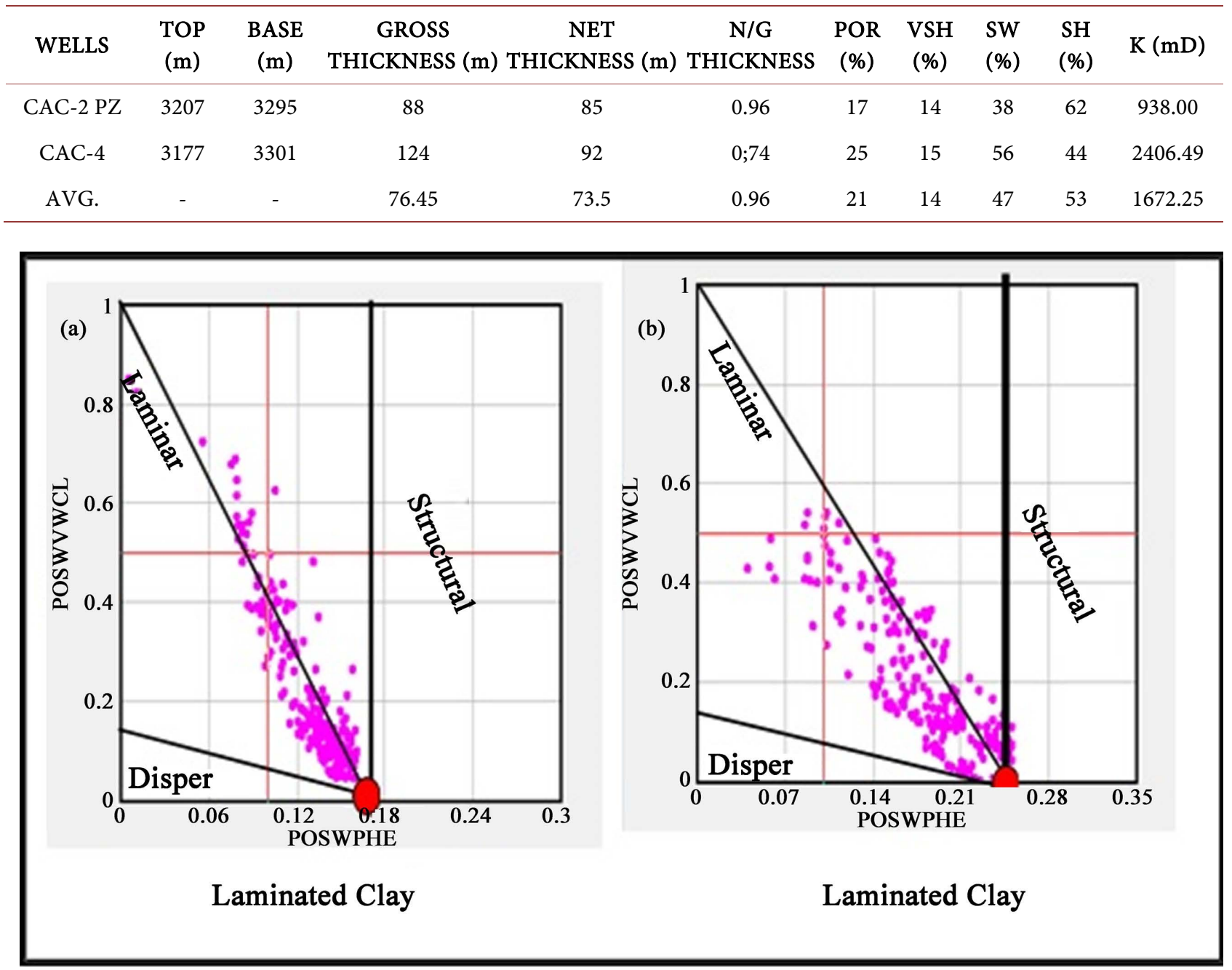

Figure 13. Cross plot of clay volume against porosity showing prevalent shale distribution pattern in RES 4 .

pattern in RES 4. The clay distribution shows that the reservoir contains only laminar clays in both wells Though laminar clays tend to reduce vertical communication of fluids, it has no adverse effect on fluid movement in well CAC-4 unlike in CAC-2 where permeability was reduced as seen from the porosity and permeability values.

Similarly, the petrophysical evaluation of reservoir RES 5 gave good average porosity and permeability are $21 \%$ and $472.2 \mathrm{mD}$ respectively. On the other hand, both the average hydrocarbon saturation and a high shale volume of 32 and $19 \%$ respectively were recorded for this reservoir. The high value of the petrophysical property irrespective of the high shale value is attributable to the influence of the type of clay content, being solely laminar clays as shown in the clay distribution plot (Figure 14). Though laminar clays tend to reduce vertical communication of fluids, it has no adverse effect on fluid movement in well CAC-4 unlike in CAC-2 where permeability was reduced as seen from the porosity and permeability values. The result of the petrophysical analysis of RES 5 
is shown in Table 3.

The petrophysical evaluation of RES 6 pay zone shows good average porosity and permeability values of $24 \%$ and $1632.32 \mathrm{mD}$. The reservoir has an average hydrocarbon saturation of $81 \%$ and a high shale volume of $19 \%$. Irrespective of this shale value, the reservoir indicates good petrophysical parameters. The above clay distribution curve shows that the reservoir contains mainly laminar and structural clays (Figure 15). The laminar and structural clays do not have an adverse effect on fluid movement in well CAC- 2 and CAC-4 as seen from the porosity and permeability values. The result of the petrophysical analysis of RES 6 is shown in Table 4.

The "RES 7" was laterally extensive across the four wells. Average values of 0.20 and $912.385 \mathrm{mD}$ were computed for the average porosity and permeability respectively, indicating good petrophysical property for the reservoir. An average shale volume and Hydrocarbon saturation of $0.19 \%$ and 0.63 respectively was determined for the reservoir. Notably the high shale value apparently did not affect the petrophysical parameter, which incidentally are high despite this high shale volume. This was later discerned to be due to the type of clay content present, being dominated by laminar and structural clays with little dispersed

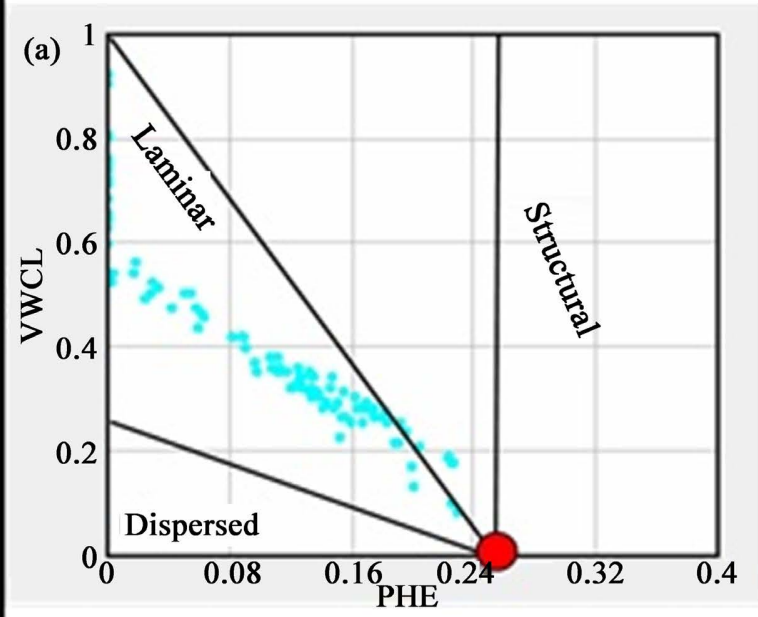

Laminated clay in CAC-2

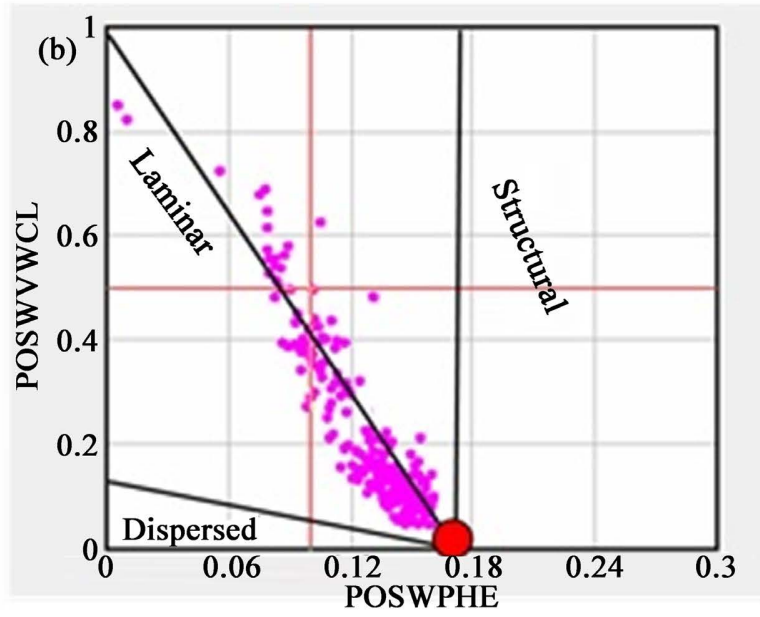

Laminated clay in CAC-4

Figure 14. Cross plot of clay volume against effective porosity showing prevalent shale distribution pattern in RES 5.

Table 3. Result of the Petrophysical analysis of "RES 5".

\begin{tabular}{ccccccccccc}
\hline WELLS & $\begin{array}{c}\text { TOP } \\
(\mathrm{m})\end{array}$ & $\begin{array}{c}\text { BASE } \\
(\mathrm{m})\end{array}$ & $\begin{array}{c}\text { GROSS }(\mathrm{m}) \\
\text { THICKNES }\end{array}$ & $\begin{array}{c}\text { NET } \\
\text { THICK }\end{array}$ & $\begin{array}{c}\text { N/G } \\
\text { THICK- }\end{array}$ & $\begin{array}{c}\text { POR } \\
(\%)\end{array}$ & $\begin{array}{c}\text { VSH } \\
(\%)\end{array}$ & $\begin{array}{c}\text { SW } \\
(\%)\end{array}$ & $\begin{array}{c}\text { SH } \\
(\%)\end{array}$ & $\begin{array}{c}\text { K (mD) } \\
\text { CAC-2 }\end{array}$ \\
3366 & 3476 & 110 & 42 & 0.38 & 25 & 21 & 41 & 59 & 240.49 \\
CAC-4 & 3343 & 3440 & 97 & 45 & 0.46 & 17 & 15 & 96 & 04 & 703.91 \\
AVG. & - & - & 104 & 44 & 0.42 & 21 & 18 & 68 & 32 & 472.2 \\
\hline
\end{tabular}




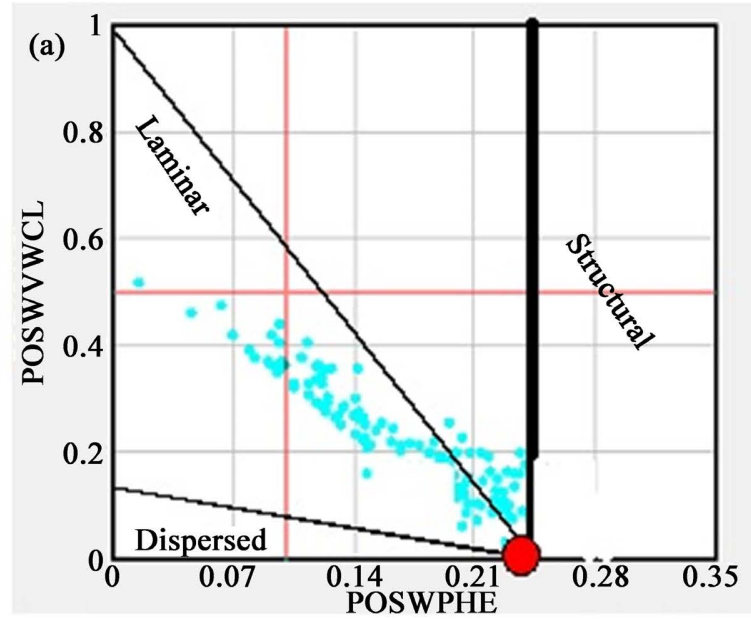

Laminated clay

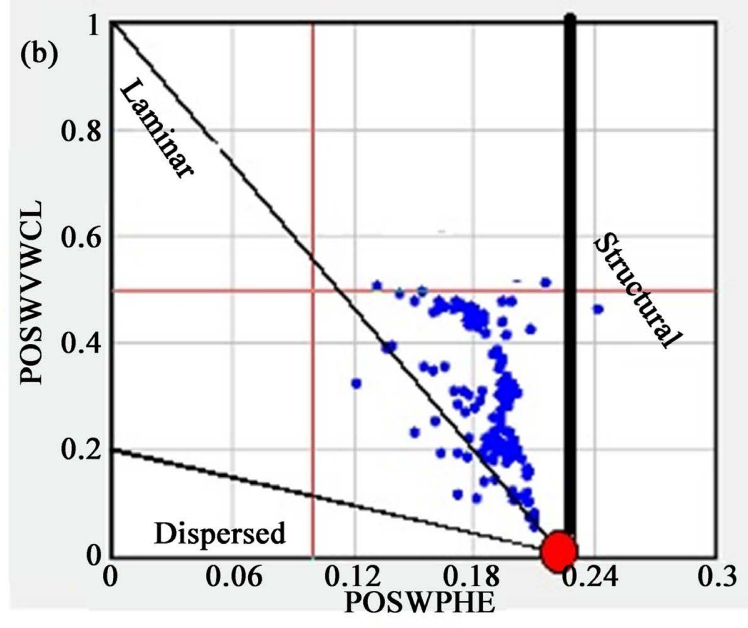

Structural and Laminated Clay

Figure 15. Cross plot of clay volume against effective porosity showing prevalent shale distribution pattern in RES 6.

Table 4. Result of the Petrophysical analysis of "RES 6".

\begin{tabular}{|c|c|c|c|c|c|c|c|c|c|c|}
\hline WELLS & $\begin{array}{l}\text { TOP } \\
(\mathrm{m})\end{array}$ & $\begin{array}{l}\text { BASE } \\
(\mathrm{m})\end{array}$ & $\begin{array}{c}\text { GROSS } \\
\text { THICKNESS } \\
\text { (m) }\end{array}$ & $\begin{array}{c}\text { NET } \\
\text { THICKNESS } \\
\text { (m) }\end{array}$ & $\begin{array}{c}\text { N/G } \\
\text { THICKNESS }\end{array}$ & $\begin{array}{c}\text { POR } \\
(\%)\end{array}$ & $\begin{array}{l}\text { VSH } \\
(\%)\end{array}$ & $\begin{array}{l}\text { SW } \\
\text { (\%) }\end{array}$ & $\begin{array}{l}\mathrm{SH} \\
(\%)\end{array}$ & $\begin{array}{c}\mathrm{K} \\
(\mathrm{mD})\end{array}$ \\
\hline CAC-2 (Pay zone & 3536 & 3596 & 60 & 57.60 & 0.96 & 24 & 13 & 23 & 77 & 1853.19 \\
\hline CAC-4 (Pay zone & 3558 & 3592 & 34 & 32.10 & 0.94 & 23 & 18 & 16 & 84 & 1411.44 \\
\hline AVG. & - & - & 46.05 & 44.85 & 0.95 & 24 & 16 & 20 & 81 & 1632.32 \\
\hline
\end{tabular}

Table 5. Result of the Petrophysical analysis of "RES 7".

\begin{tabular}{|c|c|c|c|c|c|c|c|c|c|c|}
\hline WELLS & $\begin{array}{l}\text { TOP } \\
(\mathrm{m})\end{array}$ & $\begin{array}{l}\text { BASE } \\
(\mathrm{m})\end{array}$ & $\begin{array}{c}\text { GROSS } \\
\text { THICKNESS (m) }\end{array}$ & $\begin{array}{c}\text { NET } \\
\text { THICKNESS (m) }\end{array}$ & $\begin{array}{c}\text { N/G } \\
\text { THICKNESS }\end{array}$ & $\begin{array}{l}\text { POR } \\
(\%)\end{array}$ & $\begin{array}{l}\text { VSH } \\
(\%)\end{array}$ & $\begin{array}{l}\text { SW } \\
(\%)\end{array}$ & $\begin{array}{l}\mathrm{SH} \\
(\%)\end{array}$ & $\mathrm{K}(\mathrm{mD})$ \\
\hline CAC-1 & 3750 & 3850 & 100 & 85 & 85 & 18 & 20 & 09 & 91 & 893.91 \\
\hline CAC-2 & 3795 & 3899 & 104 & 94 & 90 & 23 & 18 & 40 & 60 & 1411.44 \\
\hline CAC-3 & 3759 & 3964 & 205 & 145 & 70 & 15 & 20 & 30 & 70 & 91.00 \\
\hline CAC-4 & 3826 & 3984 & 158 & 113 & 72 & 24 & 16 & 70 & 30 & 1853.19 \\
\hline
\end{tabular}

clays, such as in CAC-3. The laminar and structural clays do not have an adverse effect on fluid movement in CAC-1, CAC-2 and CAC-4 wells whereas effective porosity and permeability were affected in CAC-3 well due to the presence of dispersed clay (Figure 16).

\section{Conclusions}

A study of the influence of shale on petrophysical properties of some selected reservoirs in "CAC-field" offshore depobelt of Niger delta was undertaken employing petrophysical logs, pre-stack seismic, deviation and check shot data. 


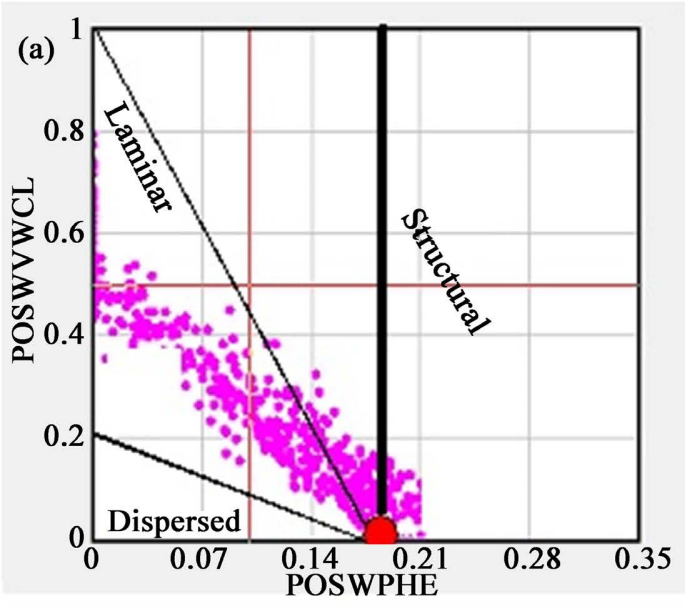

Laminated Clay

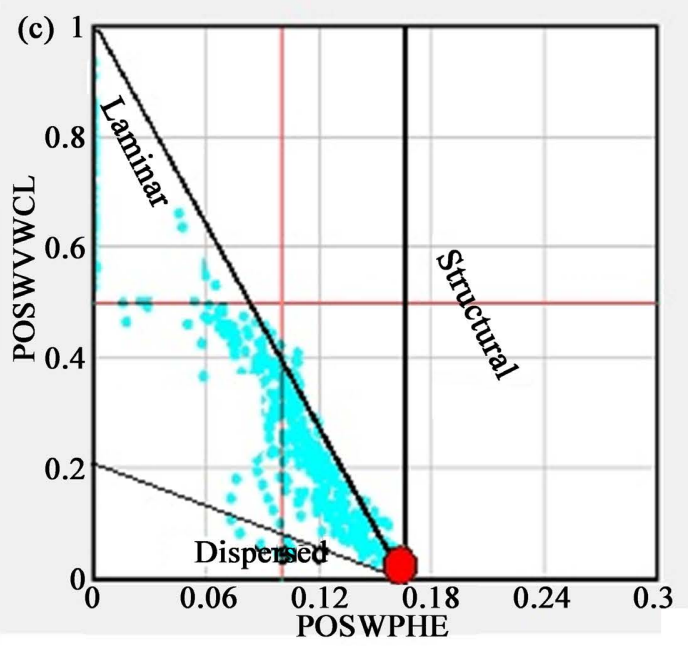

Laminated Clay

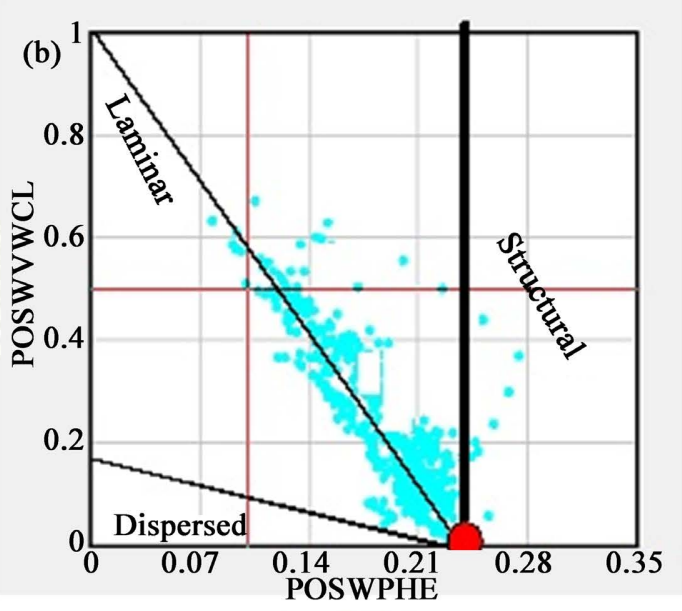

Structural and Laminated Clay

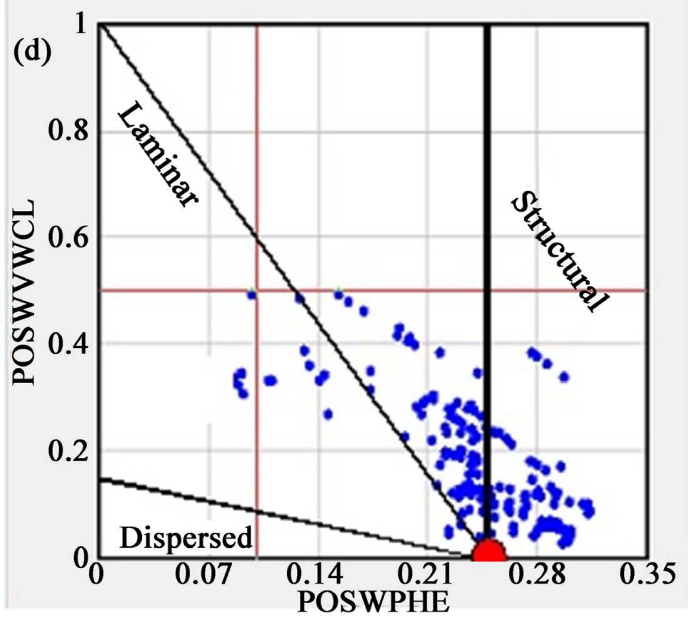

Structural and Laminated Clay

Figure 16. Cross plot of clay volume against effective porosity showing prevalent shale distribution pattern in RES 7.

This hence involved an integrated approach of well log correlation, 3D seismic data analysis, formation evaluation and clay distribution pattern. Well log correlation carried out along strike and multiple dip sections show 2 lithologies of sand and shale. Of the 12 reservoirs correlated and mapped across the study area, 4 reservoirs, RES 4 - RES 7, which are hydrocarbon bearing, laterally continuous and relatively high net-to-gross, formed the focus of this study. Formation evaluation result shows that the shale values are moderately high in the range of $13 \%-21 \%$. Irrespective of this shale value, the average porosity and permeability of the reservoirs are $18 \%-25 \%$ and $0.91-1853.19 \mathrm{mD}$ respectively. This indicates a good to excellent porosity and permeability values for hydrocarbon production. 
The dominant clay types in the reservoirs studied are the structural and laminated forms. While the structural forms have practically no influence on both the porosity and permeability of the rocks of the reservoir, the later has only little influence on the vertical flow, hence little effect on the permeability and porosity of the reservoir. Dispersed shale, on the other hand, that could impart significant baffles to flow, was only present in RES 7 of CAC-3, hence the low permeability value. This study has thus shown that understanding the nature of the shale present in a reservoir is important as it affects the assessment of reservoir quality.

\section{Acknowledgements}

The authors express their thanks to the management of Department of Petroleum Resources of Nigeria who authorized the release of the data for this research. We remain grateful to the Manager of Exploration Department, Mr. Olumuji and Mr. Peter Nwogu for the assistance all through this research.

\section{Conflicts of Interest}

The authors declare no conflicts of interest regarding the publication of this paper.

\section{References}

[1] Tiab, D. and Donaldson, E.C. (2004) Petrophysics, Theory and Practice of Measuring Reservoir and Fluid Transport Properties. 2nd Edition, Gulf Professional Publishing, New York, 881 p.

[2] Archie, G.E. (1942). The Electrical Resistivity Log as an Aid in Determining Some Reservoir Characteristics. Transactions of the AIME, 146, 54-62. https://doi.org/10.2118/942054-G

[3] Schlumberger (1991) Log Interpretation Principles/Applications. 3rd Printing Schlumberger Educational Services, Houston.

[4] Asquith, G.B. (1980) Log analysis by Microcomputer. Pennwell Publishing Company, Tulsa, $105 \mathrm{p}$.

[5] Juhasz, I. (1986) Assessment of the Distribution of Shale, Porosity and Hydrocarbon Saturation in Shaly Sands. 10th European formation evaluation symposium transactions, Aberdeen, 22-25 April 1986, Paper AA.

[6] Chukwu, G.A. (1991) The Niger Delta Complex Basin: Stratigraphy, Structure and Hydrocarbon Potential. Journal of Petroleum Geology, 14, 211-220.

https://doi.org/10.1111/j.1747-5457.1991.tb00363.x

[7] Mode, A.W. and Anyiam, O.A. (2007). Reservoir Characterization Implications from Petrophysical Data of the "Parardise Field", Niger Delta, Nigeria. American Journal of Scientific and Industrial Research, 1, 262-270.

[8] Petroskills (2010) Basic Petroleum Geology.

[9] Anyiam, O., Mode, A.W. and Ekwe, A. (2010) Formation Evaluation of an Onshore Appraisal Well "KG-5”, “Green Field”, Niger Delta. Nigeria American Journal of Scientific and Industrial Research, 1, 262-270.

https://doi.org/10.5251/ajsir.2010.1.2.262.270 
[10] Mode, A.W., Adepehin, E.J. and Anyiam, O.A. (2013) Petrophysical Effects of Clay Heterogeneity on Reservoirs' Properties: Case Study of "Brown Field” Niger Delta, Nigeria. Nigerian Association of Petroleum Explorionists Bulletin, 25, 61-67.

[11] Ajisafe, Y.C. and Ako, B.D. (2013) 3D Seismic Attributes for Reservoir Characterization of ' $\mathrm{Y}$ ' Field Niger Delta, Nigeria. IOSR Journal of Applied Geology and Geophysics, 1, 23-31.

[12] Anyiam, O.A, Andrew, P.J. and Okwara, I.C. (2017) Assessment of the Heterogeneity and Petrophysical Evaluation of Reservoirs in the "Akbar Field”, Niger Delta, Nigeria. Journal of Petroleum Exploration and Production Technology, 7, 1035-1050. https://doi.org/10.1007/s13202-017-0361-Z

[13] Anyiam, O.A, Mode, A.W. and Okwara, E.S. (2018) The Use of Crossplots in Lithology Delineation and Petrophysical Evaluation of some Wells in the Western Coastal, Niger Delta. Nigeria. Journal of Petroleum Exploration and Production Technology, 8, 61-71. https://doi.org/10.1007/s13202-017-0364-9

[14] Eje, E.O. and Ideozu, R.U. (2018) Effects of Shale Volume Distribution on the Elastic Properties of Reservoirs in Nan tin Field Offshore Niger Delta. Journal of Applied Geology and Geophysics, 6, 68-85.

[15] Fozao, K.F., Djieto-Lordon, A.E., Ali, E.A, Agying, C.M, Ndeh, D.M. and Zebaze, M.K. (2019) Analysis of Shaly Sand Reservoir Rocks in the Eastern Niger Delta Basin Using Geophysical Well Logs. Journal of Petroleum and Gas Engineering, 10, 1-13. https://doi.org/10.5897/JPGE2018.0300

[16] Kulke, H. (1995) Petroleum Geology of Nigeria, In: Kulke, H., Ed., Regional Petroleum Geology of the World, Part II, Africa, America, Australia and Antarctica, Gebruder Borntraeger, Berlin, 143-172.

[17] Tuttle, L.W., Charpentier, R.R. and Brownfeld, M.E. (1999) The Niger Delta Petroleum System: Niger Delta province, Nigeria, Cameroon and Equatorial Guinea Africa. Open-File Report 99-50-H, United States Geological Survey, Arlington. https://doi.org/10.3133/ofr9950H

[18] Ekweozor, C.M. and Daukoru, E.M. (1994) Northern Delta Depobelt Portion of the Akata-Agbada Petroleum System, Niger Delta, Nigeria. In: Magoon, L.B. and Dow, W.G., Eds., The Petroleum System-From Source to Trap, AAPG Memoir 60: Tulsa, American Association of Petroleum Geologists, American Association of Petroleum Geologists, Tulsa, 599-614. https://doi.org/10.1306/M60585C36

[19] Reyment, R.A. (1965) Aspects of the Geology of Nigeria. Ibadan University Press. Ibadan.

[20] Short, K.C. and Stauble, A.J. (1967) Outline of the Geology of the Niger Delta. AAPG Bulletin, 51, 761-779. https://doi.org/10.1306/5D25C0CF-16C1-11D7-8645000102C1865D

[21] Merki, P. (1972). Structural Geology of the Cenozoic Niger Delta. In: Dessauvagie, T.F.J. and Whiteman, A.J., Eds., African Geology, Ibadan University Press, Ibadan, 635-646.

[22] Weber, K.J. and Daukoru, E.M. (1975) Petroleum Geological Aspects of the Niger Delta. Journal of Mining and Geology, 12, 1-22.

[23] Avbovbo, A.A. (1978) Tertiary Lithostratigraphy of Niger Delta: Geologic Notes. AAPG Bulletin, 62, 295-300. https://doi.org/10.1306/C1EA482E-16C9-11D7-8645000102C1865D

[24] Evamy, B.D., Haremboure, J., Kamerling, P., Knaap, W.A., Molloy, F.A., and Rowlands, P.H. (1978). Hydrocarbon Habitat of Tertiary Niger Delta. AAPG Bulletin, 
62, 1-39. https://doi.org/10.1306/C1EA47ED-16C9-11D7-8645000102C1865D

[25] Whiteman, A.J. (1982) Nigeria: Its Petroleum Geology, Resources and Potential. Springer, Dordrecht, 176, 238. https://doi.org/10.1007/978-94-009-7361-9

[26] Doust, H. (1990) Petroleum Geology of the Niger Delta. Special Publications. Geological Society, London, Special Publications, 50, 365. https://doi.org/10.1144/GSL.SP.1990.050.01.21

[27] Stacher, P. (1995) Present Understanding of the Niger Delta Hydrocarbon Habitat. In: Oti, M.N. and Postma, G., Eds., Geology of Deltas, A.A. Balkema, Rotterdam, 257-267.

[28] Hammed, O., Awoyemi, M., Igboama, W.N., Ebun, D., Fatoba, J., Olurin, O.T., et al. (1996) Three Dimensional Seismic, Well Log, and Structural Analysis of "Igbobi" Field, Offshore Niger Delta. Petroleum and Coal, 59, 620-640.

https://www.vurup.sk/na stiahnutie/three-dimensional-seismic-well-log-structuralanalysis-igbobi-field-offshore-niger-delta/

[29] Armentrout, J.M., Kanschat, K.A., Meisling, K.E., Tsakma, J.J., Antrim, L. and McConnell, D.R. (2000) Chapter 9: Neogene Turbidite Systems of the Gulf of Guinea Continental Margin Slope, Offshore Nigeria. In: Bouma, A.H. and Stone, C.G., Eds., Fine-Grained Turbidite Systems, American Association of Petroleum Geologists, Tulsa. https://doi.org/10.1306/M72703C9

[30] Matava, T., Rooney, M., Moses Chung, H., Nwankwo, B.C., Unomah, G.I. (2003) Migration Effects on the Composition of Hydrocarbon Accumulations in the OML 67 - 70 Areas of the Niger Delta. American Association of Petroleum Geologists Bulletin, 87, 1193-1206. https://doi.org/10.1306/02190300116

[31] Esedo, R. and Ozumba, B. (2005) New Opportunity Identification in a Mature Basin: The Oguta North Prospect in OML 20, Niger Delta. Nigeria Annual International Conference, Abuja, August 2005, Paper No. SPE-98812-MS. https://doi.org/10.2118/98812-MS

[32] Selley, R.C. (1985) Ancient Sedimentary Environment and their Subsurface Diagnosis. 3rd Edition, Chapman and Hall Ltd., London, 317 p.

[33] Doust, H. and Omatsola, E. (1990) Niger Delta. In: Edwards, J.D. and Santogrossi, P.A., Eds., Divergent/ Passive Margin Basins, AAPG Memoir, Vol. 48, 239-248.

[34] Mheluka, J.M. and Mulibo, G.D. (2018) Petrophysical Analysis of the Mpera Well in the Exploration Block 7, Offshore Tanzania: Implication on Hydrocarbon Reservoir Rock Potential. Open Journal of Geology, 8, 803-818. https://doi.org/10.4236/ojg.2018.88047

[35] Hilchie, D.W. (1978) Applied Openhole Log Interpretation. Douglas W. Hilchie Inc., Golden, 161. 